Jurnal Kesmas Asclepius

Volume 1, Nomor 2, Desember 2019

e-ISSN: 2684-8287

p-ISSN: 2656-8926

DOI: https://doi.org/10.31539/jka.v1i2.886

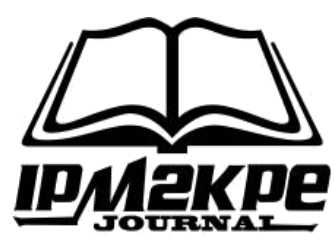

\title{
HUBUNGAN PENDIDIKAN DAN PEKERJAAN IBU DENGAN PEMAKAIAN ALAT KONTRASEPSI DALAM RAHIM (AKDR)
}

\author{
Lia Hartini \\ Penyuluh Keluarga Berencana Kota Lubuklinggau \\ liahartini65@gmail.com
}

\begin{abstract}
ABSTRAK
Tujuan penelitian untuk mengetahui adakah hubungan pendidikan dan pekerjaan ibu dengan pemakaian Alat Kontrasepsi Dalam Rahim (AKDR) di Puskesmas Taba Kota Lubuklinggau tahun 2019. Metode penelitian menggunakan metode survey analitik dengan pendekatan cross sectional. Hasil analisis univariat didapatkan dari 50 akseptor diketahui sebagian kecil responden tidak memakai kontrasepsi AKDR sebanyak 9 responden (18\%), responden pada kategori pendidikan sebagian responden berpendidikan rendah yaitu sebanyak 30 responden $(60 \%)$ pada kategori pekerjaan (mempunyai pekerjaan baik) berjumlah 22 responden (44\%). Simpulan, ada hubungan yang bermakna antara pendidikan ibu dengan pemakaian AKDR. Tidak ada hubungan antara pekerjaan ibu dengan pemakaian AKDR tidak terbukti secara statistik.
\end{abstract}

Kata Kunci : Pekerjaan, Pemakaian AKDR, Pendidikan

\section{ABSTRACT}

The purpose of this study was to determine whether there was a relationship between education and occupation of the mother with the use of contraceptive devices in the womb at the Taba Puskesmas Lubuklinggau in 2019. The research method used an analytical survey method with a cross sectional approach. Univariate analysis results obtained from 50 acceptors revealed that a small proportion of respondents did not use contraceptive IUD as many as 9 respondents (18\%), respondents in the education category most respondents were educated as many as 30 respondents (60\%) in the occupational category (having good jobs) totaling 22 respondents (44\%). In conclusion, there is a significant relationship between mother's education and the use of the IUD. no relationship between maternal occupation and IUD use was not statistically proven.

Keywords: Employment, IUD Use, Education

\section{PENDAHULUAN}

Berdasarkan World Populations Data Sheet 2010 pada pertengahan tahun 2010 Indonesia merupakan peringkat satu negara dengan penduduk tertinggi di ASEAN, dengan jumlah penduduk 235,5 juta jiwa, sedangkan yang terendah yaitu Brunei Darusslam yaitu 0,4 jiwa (Depkes RI, 2011).

Menurut profil Kesehatan Indonesia tahun 2010, angka kelahiran di Indonesia berjumlah 20 kelahiran per 1000 penduduk, sehingga Indonesia menempati posisi kelima tertinggi di ASEAN (Depkes RI, 2011). Salah satu kebijakan dalam menanggulangi masalah kependudukan di Indonesia adalah dengan memberikan 
pengetahuan tentang kependudukan dan $\mathrm{KB}$ yaitu manfaat $\mathrm{KB}$ adalah untuk menekankan jumlah kepadatan penduduk, program KB menentukan kualitas keluarga, karena program ini dapat menyelamatkan kehidupan perempuan serta meningkatkan status kesehatan ibu terutama dalam mencegah kehamilan yang tak diinginkan, menjarangkan jarak kelahiran, mengurangi resiko kematian bayi.

Menurut WHO (World Health Organitation) keluarga berencana adalah tindakan yang membantu pasangan suami istri untuk menghindari kehamilan yang tidak diinginkan, mendapatkan kelahiran yang memang sangat diinginkan, mengatur interval diantara kehamilan, mengontrol waktu saat kehamilan dalam hubungan dengan umur suami istri serta menentukan jumlah anak dalam keluarga (Suratun, 2008).

Sedangkan Keluarga Berencana (KB) artinya mengatur jumlah anak sesuai dengan kehendak dan menentukan sendiri kapan ingin hamil. Bila anda memutuskan untuk tidak segera hamil sesudah menikah, anda bisa ber KB. Layanan KB di seluruh Indonesia mudah diperoleh. Ada beberapa metode pencegahan kehamilan/penjarangan kehamilan / kontrasepsi yang bisa dipilih sendiri (Maulana, 2008).

Selain memberi keuntungan ekonomi pada pasangan suami istri, keluarga dan masyarakat, KB juga membantu remaja mengambil keputusan untuk memilih kehidupan yang lebih baik dengan merencanakan proses reproduksinya. Program KB bisa meningkatkan pria untuk ikut bertanggungjawab dalam kesehatan reproduksi mereka dan keluarganya. Ini merupakan keuntungan seseorang mengikuti program KB (BKKBN, 2009).

Kontrasepsi menghindari/mencegah terjadinya kehamilan sebagai akibat adanya pertemuan antara sel telur dengan sperma (Suratun, 2008). Kontrasepsi adalah upaya mencegah kehamilan (Winkjosastro, 2008). Sementara pengertian AKDR atau IUD itu sendiri adalah suatu alat atau benda yang dimasukkan ke dalam rahim yang sangat efektif, reversibel dan jangka panjang, dapat dipakai oleh semua perempuan usia produktif (Saifuddin, 2006).

Suntik dan pil adalah cara KB modern yang paling diketahui oleh masyarakat di semua golongan usia risiko tinggi di atas 35 tahun, namun kedua jenis alat kontrasepsi tersebut dinilai kurang efektif untuk mencegah kehamilan. Jenis kontrasepsi yang efektif untuk mencegah kehamilan bagi wanita risiko tinggi adalah AKDR, sterilisasi wanita dan sterilisasi pria. Untuk saat ini, pemerintah menyediakan secara gratis tiga jenis alat kontrasepsi di seluruh wilayah Indonesia, yaitu kondom, AKDR, dan implan (Kemenkes, 2013).

AKDR adalah suatu usaha pencegahan kehamilan dengan menggulung secarik kertas, diikat dengan benang lalu dimasukkan ke dalam rongga rahim (Prawirohardjo, 2003). Menurut BKKBN (2009) AKDR atau IUD atau spiral adalah suatu benda kecil yang terbuat dari plastik yang lentur, mempunyai lilitan tembaga atau juga mengandung hormon dan dimasukkan ke dalam rahim melalui vagina dan mempunyai benang.

AKDR adalah alat kontrasepsi yang terbuat dari plastik disertai barium sulfat dan mengandung tembaga, progesteron (progesterone $\mathrm{T}$ Progestasert system) atau levonorgestrel (Mirena) (Liando et al., 2013). AKDR adalah suatu alat untuk mencegah kehamilan yang efektif, aman dan reversibel yang terbuat dari plastik atau logam kecil yang dimasukkan ke dalam uterus melalui kanalis servikalis (WHO, 2007).

Pembangunan Gerakan Keluarga Berencana Nasional ditujukan terutama untuk meningkatkan kualitas sumber daya manusia. Keluarga sebagai kelompok sumber daya manusia terkecil yang mempunyai ikatan batiniah dan lahiriah yang merupakan 
pengembangan sasaran dalam mengupayakan terwujudnya visi Keluarga Berencana Nasional (Saifudin, 2006).

Gerakan Keluarga Berencana Nasional telah menunjukkan hasil yang menggembirakan. Kemampuan untuk membatasi jumlah anak melalui penggunaan berbagai alat kontrasepsi membuahkan hasil nyata, yaitu semakin sedikitnya rata-rata jumlah anak yang dilahirkan yaitu TFR pada tahun 1977 rata-rata setiap keluarga mempunyai 2,78 anak dan menurut SDKI pada tahun 2002 TFR menurun menjadi 2,6 anak, tetapi hasil tersebut belum memberikan kondisi ideal untuk pertumbuhan penduduk seimbang yaitu 2,1 anak (BKKBN, 2009).

Dari hasil SDKI (Survey Demografi dan Kesehatan Indonesia) tahun 2002-2003 diketahui jumlah pemakai konttasepsi adalah 56,7 \% dengan rincian Intra Uteri Device /IUD (6,2\%), Pil 13,2\%, Suntik (27,8\%), Implant (4,3\%), Metode Operasi Wanita /MOW (3,7\%), Metode Operasi Pria/MOP (0,4\%) serta kondom (0,9\%). Sementara cara tradisional / alamiah mencapai $(3,6 \%)$ yang terdiri dari pantang berkala $(1,6 \%)$ dan cara lain $(0,5 \%)$.

Menurut Hanafi (2008) masyarakat dapat menerima hampir semua metode teknis Keluarga Berencana (KB) yang direncanakan oleh pemerintah seperti pil, suntik, sondom, iud, implant, metode operasi. Menurut Biran (2012) faktor-faktor yang berhubungan dengan pemakaian alat kontrasepsi IUD yaitu umur, pendidikan, pengetahuan, dukungan suami, pekerjaan.

Berdasarkan data dari BKKBN (2011) Penggunaan kontrasepsi IUD menduduki tingkat keempat yaitu sebesar $(5,8 \%)$, suntik $(45,95 \%)$, pil kb $(28,52 \%)$, implant $(8,90 \%)$, mop $(0,18 \%)$, mow $(1,05 \%)$ dan kontrasepsi kondom $(9,58 \%)$. Sedangkan data profil kesehatan Indonesia tahun 2010 menyebutkan bahwa dari 44.738.378 PUS, yang menjadi peserta KB Aktif sebanyak 33.713 .115 (75,36\%) yang menggunakan kontrasepsi IUD yaitu sebesar (11.03\%), suntikan (47,19\%), pil (26,81\%), implant $(8,26 \%)$, kondom $(2,50 \%)$, MOW $(3,53 \%)$ dan yang paling rendah adalah MOP yaitu $(0,68 \%)$.

Banyak faktor yang menyebabkan akseptor $\mathrm{KB}$ menggunakan jenis kontrasepsi tertentu. Faktor yang mempengaruhi yaitu umur, status laktasi, keadaan ekonomi, keadaan kesehatan, kebutuhan, jumlah anak, sosial budaya, pendidikan, pekerjaan. Dari survey prevalensi kontrasepsi diketahui bahwa ibu-ibu dengan proporsi umur wanita pemakai kontrasepsi pada kelompok umur 30-40 tahun (59\%). Pil dan suntik terbesar digunakan wanita kelompok umur 20-30 tahun sedangkan jenis kontrasepsi lainnya yaitu IUD, kondom dan kontap dipakai pada kelompok umur lebih dari 30 tahun (BKKBN, 2009).

Dari profil Kesehatan Sumatera Selatan pada tahun 2009 didapatkan data akseptor sejumlah 1.050.605 atau sebesar (74,38\%) dari sebanyak 1.412.394 PUS tahun 2009. Dengan pemakaian kontrasepsi sebagai berikut: pil 319.546, suntik 450.004, kondom 19,762, MOP 3.445, MOW 40.649, implant 170.436, dan IUD 46.763. Jumlah memakai kontrasepsi kontrasepsi jangka pendek pil, suntik, dan kondom adalah 789.312 atau $(55,90 \%)$ dari total PUS atau $(75,13 \%)$ dari total pencapaian tahun 2009. 


\section{METODE PENELITIAN}

Jenis Penelitian ini bersifat kuantitatif dengan menggunakan metode survey Analitik melalui pendekatan cross sectional. Populasi dalam penelitian ini adalah semua ibu yang menggunakan alat kontrasepsi yang berkunjung di Puskesmas Taba pada bulan Agustus tahun 2019 sebanyak 1769 akseptor. Sampel adalah sebagian dari populasi yang mewakili suatu populasi.

Cara pengambilan sampel menggunakan teknik accidental sampling, yaitu teknik penentuan sampel berdasarkan kebetulan, yaitu siapa saja yang yang secara kebetulan bertemu dengan peneliti melakukan penelitian dari tanggal 01 sampai dengan 28 Agustus 2019 dan dapat digunakan sebagai sampel, bila orang yang kebetulan ditemui itu cocok sebagai sumber data. Sample diambil dari keseluruhan objek yang diteliti yaitu semua akseptor KB yang berkunjung di Puskesmas Taba kota Lubuklinggau.

Sedangkan kriteria sampel adalah bersedia menjadi responden (bisa membaca dan menulis) dan sebagai akseptor KB yang berkunjung di Puskesmas Taba Kota Lubuklinggau. Tempat penelitian dilakukan di Puskesmas Taba Kota Lubuklinggau. Pengambilan data terhadap sampel penelitian dilakukan oleh peneliti dengan cara checklist yang berisi pertanyaan dan diajukan secara tertulis untuk mendapatkan keterangan. Adapun sumber data adalah 1. Data primer yaitu pengumpulan data dilakukan dengan cara checklist yang berisi pertanyaan dan diajukan secara tertulis Responden pada peneliti adalah ibu yang menggunakan KB yang berkunjung di Puskesmas Taba Kota Lubuklinggau tahun 2019. 2. Data sekunder adalah data yang diperoleh dari dinas pengendalian penduduk dan keluarga berencana kota Lubuklinggau, internet, buku, kesehatan, buku kependudukan yang berkaitan dengan judul penelitian.

Teknik pengumpulan data dikumpulkan dengan menggunakan cara checklist yang berisi pertanyaan dan diajukan secara tertulis. Sedangkan teknik pengolahan data menggunakan coding, editing, entry, dan cleaning.

Adapun teknik analis data yang digunakan adalah analisis univariat dan analisis bivariat. Analisis univariat dilakukan terhadap variabel dari hasil penelitian, dalam analisis ini hanya menghasilkan distribusi dan persentase dari tiap variabel. Pada penelitian ini analisis univariat dilakukan pada variabel independent (pendidikan dan pekerjaan) dengan variabel dependen (pemakaian AKDR) untuk menjelaskan atau mendeskripsikan karakteristik setiap variabel penelitian yaitu faktor-faktor yang berhubungan dengan penggunaan alat kontrasepsi di Puskesmas Taba Kota Lubuklinggau tahun 2019. Sedangkan analisis bivariat dilakukan terhadap dua variabel yang diduga berhubungan atau korelasi.

\section{HASIL PENELITIAN}

Tabel.1

Distribusi Frekuensi

Pemakaian AKDR

\begin{tabular}{llllll}
\hline & & Frequency & Percent & Valid Percent & $\begin{array}{c}\text { Cumulatif } \\
\text { Percent }\end{array}$ \\
Valid & Ya & 9 & 18.0 & 18.0 & 18.0 \\
& Tidak & 41 & 82.0 & 82.0 & 100.0 \\
& Total & 50 & 100.0 & 100.0 & \\
\hline
\end{tabular}


Berdasarkan tabel 1, dapat diketahui bahwa penamakaian AKDR di Puskesmas Taba Kota Lubuklinggaudari responden sebanyak 50 orang hanya 9 orang (18\%) ibu yang menggunakan kontrasepsi AKDR.

Tabel. 2

Distribusi Frekuensi Responden Berdasarkan Pendidikan

\begin{tabular}{cccccc}
\hline & & Frequency & Percent & Valid Percent & $\begin{array}{c}\text { Cumulatif } \\
\text { Percent }\end{array}$ \\
Valid & Tinggi & 20 & 40.0 & 40.0 & 40.0 \\
& Rendah & 30 & 60.0 & 60.0 & 100.0 \\
& Total & 50 & 100.0 & 100.0 & \\
\hline
\end{tabular}

Berdasarkan tabel 2, dapat diketahui bahwa distribusi responden berdasarkan pendidikan ibu akseptor KB aktif dari 50 responden sebanyak 20 responden (40\%), yang berpendidikan tinggi dari 30 responden $(60 \%)$.

Tabel.3

Distribusi Frekuensi Responden

Berdasarkan Pekerjaan

\begin{tabular}{llllll}
\hline & & Frequency & \multicolumn{1}{c}{ Percent } & Valid Percent & $\begin{array}{c}\text { Cumulatif } \\
\text { Percent }\end{array}$ \\
Valid & Baik & 22 & 44.0 & 44.0 & 44.0 \\
& Kurang & 28 & 56.0 & 56.0 & 100.0 \\
& Total & 50 & 100.0 & 100.0 & \\
\hline
\end{tabular}

Berdasarkan tabel 3, dapat diketahui distribusi responden berdasarkan pekerjaan bahwa dari 50 responden sebanyak 22 responden $(44.0 \%)$ mempunyai pekerjaan baikdan sebanyak 28 responden $(56 \%)$ yang mempunyai pekerjaan kurang.

Tabel. 4

Hubungan antara Pendidikan Responden dengan Pemakaian AKDR

\begin{tabular}{cccccccc}
\hline \multirow{2}{*}{ Pendidikan } & \multicolumn{4}{c}{ Pemakaian AKDR } & \multicolumn{2}{c}{ Total } & \multirow{2}{*}{ P Value } \\
& $\mathrm{N}$ & $\%$ & $\mathrm{~N}$ & $\%$ & $\mathrm{~N}$ & $\%$ & \\
\hline Tinggi & 7 & 35.0 & 13 & 65.0 & 20 & 100 & 0.029 \\
Rendah & 2 & 6.7 & 28 & 93.3 & 30 & 100 & \\
Jumlah & 9 & 18.0 & 41 & 82.0 & 50 & 100 & \\
\hline
\end{tabular}

Tabel 4, memperlihatkan bahwa responden yang berpendidikan tinggi dari 20 responden didapatkan 7 responden (35\%) menggunakan AKDR dan sebanyak 13 responden $(65 \%)$ tidak menggunakan AKDR, sedangkan dari 30 responden dengan kategori pendidikan rendah dari 30 responden didapatkan 2 responden $(6,7 \%)$ menggunakan AKDR dan sebanyak 28 responden (93,3\%) tidak menggunakan AKDR. Hasil Uji Statistik chi-square diperoleh $\rho=0,1029<$ 圆 0,05 dengan demikian menunjukkan adanya hubungan yang bermakna antara pendidikan ibu dengan pemakaian AKDR. 
Tabel. 5

Hubungan antara Pekerjaan dengan

Pemakaian AKDR

\begin{tabular}{lcccccccc}
\hline & \multicolumn{4}{c}{ Suntik } & \multicolumn{2}{c}{} & P \\
& \multicolumn{2}{c}{ Ya } & \multicolumn{2}{c}{ Tidak } & \multicolumn{2}{c}{ Total } & Value \\
\multicolumn{1}{c}{ Pekerjaan } & $\mathrm{N}$ & $\%$ & $\mathrm{~N}$ & $\%$ & $\mathrm{~N}$ & $\%$ & \\
\hline Baik & 7 & 31.8 & 15 & 68.2 & 22 & 100 & 0,060 \\
Kurang Baik & 2 & 7.1 & 26 & 92.9 & 28 & 100 & \\
Jumlah & 9 & 82 & 41 & 82 & 50 & 100 & \\
\hline
\end{tabular}

Tabel 5 memperlihatkan bahwa responden dengan kategori baik (mempunyai pekerjaan) didapatkan 7 responden $(31,8 \%)$ menggunakan ADKR dan sebanyak 15 responden $(68,2 \%)$ tidak menggunakan AKDR. Sedangkan dari 28 respondendengan kategori kurang baik (tidak mempunyai pekerjaan) didapatkan 2 responden $(7,1 \%)$ menggunakan AKDR dan yang tidak menggunakan AKDR sebanyak 26 responden $(92,2 \%)$. Hasil Uji Statistik diperoleh $\rho$ value 0,060> 0,05 dengan demikian tidak ada hubungan yang bermakna antara pekerjaan dengan pemakaian AKDR.

\section{PEMBAHASAN}

Penelitian dilakukan di Puskesmas Taba Kota Lubuklinggau dengan jumlah populasi penelitian sebanyak 50 responden sehingga dengan menggunakan rumus Notoatmodjo (2005) yaitu seluruh populasi dijadikan sampel. Sampel penelitian adalah semua ibu akseptor KB aktif di Puskesmas Taba Kota Lubuklinggau yang datanya diperoleh dari rekam medik dan sampel diambil dengan teknik pengambilan sampel accidental sampling yaitu sebagian dari akseptor KB yang datang berkunjung di Puskesmas Taba baik sehat maupun sakit pada saat penelitian berlangsung. Kemudian data yang telah dikumpulkan diolah dan dilakukan analisis data terdiri dari analisis univariat dan analisis bivariat. Pada analisis dilakukan uji statistik chi-square dengan menggunakan komputerisasi.

Pendidikan responden paling banyak adalah SMA, sehingga dapat dikatakan bahwa responden memiliki pendidikan relatif cukup. Pendidikan responden yang cukup mengakibatkan responden mudah menerima informasi tentang tentang KB IUD. Namun sebagian responden memiliki pengetahuan tentang KB IUD termasuk kurang, karena sebagian responden pada penelitian memiliki pendidikan relatif rendah yaitu hanya memiliki latar belakang pendidikan SMP dan umur sebagian responden masih relatif rendah yaitu dibawah 20 tahun. Pendidikan yang relatif rendah mengakibatkan responden lebih sulit menerima informasi dibandingkan yang berpendidikan lebih tinggi dan umur yang relatif rendah berkaitan dengan pengalaman yang merupakan salah satu faktor yang mempengaruhi pengetahuan seseorang.

Dengan pendidikan tinggi seseorang akan cenderung mendapatkan informasi, baik dari orang lain maupun dari media massa, sebaliknya tingkat pendidikan yang kurang akan menghambat perkembangan dan sikap seseorang terhadap nilai-nilai yang baru diperkenalkan (Nursalam, 2002).

Hasil penelitian ini sejalan dengan penelitian yang dilakukan oleh Asra (2010) yang berjudul faktor-faktor yang berhubungan dengan penggunaan Alat Kontrasepsi Dalam Rahim pada akseptor KB di wilayah kerja Puskesmas Balai Makam Duri bahwa ada hubungan yang signifikan antara pendidikan dengan pengguna kontrasepsi IUD. 
Hasil penelitian ini juga sejalan dengan penelitian yang dilakukan Armainar (2011) yang berjudul faktor-faktor yang mempengaruhi akseptor KB dalam memilih Alat Kontrasepsi Dalam Rahim(AKDR) di wilayah kerja Puskesmas Minas Kabupaten Siak, bahwa ada hubungan yang signifikan antara pendidikan dengan perilaku pemakaian AKDR.

Hal ini sejalan dengan penelitian Armainar (2011) yang berjudul faktor-faktor yang mempengaruhi akseptor KB dalam memilih AKDR di wilayah kerja Puskesmas Minas Kabupaten Siak, bahwa ada hubungan yang signifikan antara pengetahuan dengan perilaku pemakaian (Pitriani, 2015).

Hal ini menyimpulkan bahwa ibu yang berpendidikan di SMA memiliki pengetahuan yang luas dan daya tangkap yang cukup baik dalam mendapatkan informasi. Pada penelitian ini pekerjaan ibu dibagi menjadi dua kategori yaitu baik (bekerja) dan kurang (tidak bekerja).

Bekerja umumnya merupakan kegiatan yang menyita waktu bekerja bagi ibu-ibu akan mempunyai pengaruh terhadap keluarga. Pekerjaan dari peserta KB dan suami akan mempengaruhi pendapatan dan status ekonomi keluarga. Suatu keluarga dengan status ekonomi atas terdapat perilaku Fertilitas yang mendorong terbentuknya keluarga besar. Status pekerjaan dapat berpengaruh terhadap keikutsertaan dalam KB karena adanya faktor pengaruh lingkungan pekerjaan yang mendorong seseorang untuk ikut dalam KB, sehingga secara tidak langsung akan mempengaruhi status dalam pemakaian kontrasepsi (Gungde, 2008).

Banyak perempuan yang mengalami kesulitan dalam menentukan pilihan jenis kontrasepsi. Hal ini tidak hanya karena terbatasnya metode yang tersedia, tetapi juga oleh ketidaktahuan mereka tentang persyaratan dan keamanan metode kontrasepsi tersebut. Berbagai faktor harus dipertimbangkan termasuk status kesehatan, efek samping, potensial, konsekuensi kegagalan/kehamilan yang tidak diinginkan, besar keluarga yang direncanakan, persetujuan pasangan bahkan norma budaya lingkungan integral yang tinggi dalam pelayanan (BKKBN, 2005).

Seorang yang memiliki pengetahuan baik akan cenderung memilih alat kontrasepsi yang sesuai dan cocok digunakannya. Karena dengan pengetahuan yang baik seseorang akan lebih mudah menerima informasi terutama tentang alat kontrasepsi (Nursalam, 2002).

Hal ini tidak sesuai dengan pendapat Nursalam (2002) yang mengatakan bahwa pada umumnya pengetahuan seseorang dipengaruhi oleh pendidikan yang pernah diterima, semakin tinggi tingkat pendidikan seseorang maka semakin baik pula tingkat pengetahuannya. Belum tentu orang yang berpendidikan tinggi itu pengetahuannya lebih tinggi. Semua itu tergantung keaktifan wanita pasangan usia subur dalam mencari dan menerima informasi tentang AKDR.

Semakin tinggi pendidikan seseorang maka diharapkan pengetahuan dan keterampilan akan semakin meningkat. Pendidikan dianggap memiliki peran penting dalam menentukan kualitas manusianya, lewat pendidikan manusia dianggap akan memperoleh pengetahuan implikasinya, semakin tinggi pendidikan seseorang akan semakin berkualitas (Hurlock, 2004). Pendidikan merupakan formal yang pernah ditempuh seseorang untuk mendapatkan pengetahuan sampai dengan memperoleh ijazah terakhir. Pendidikan adalah suatu proses pengembangan kemampuan (perilaku) ke arah yang diinginkan, pendidikan mencakup pengalaman, pengertian dan penyesuaian diri dari pihak terdidik terhadap rangsangan yang diberikan kepadanya menuju kearah pertumbuhan dan perkembangan (Notoatmodjo, 2005). 
Tingkat pengetahuan akan sangat mempengaruhi penggunaan AKDR. Selain itu, faktor sosio-demografi (usia wanita, status pendidikan suami maupun istri, agama, karakteristik keluarga) secara langsung juga mempengaruhi penerimaan AKDR (Rathi \& Jawadagi, 2014).

Sementara pekerjaan merupakan kegiatan yang dilakukan suami/istri untuk memenuhi kebutuhan sehari-hari. Di daerah kota dan semi perkotaan, ada kecenderungan rendahnya frekuensi penggunaan IUD pada ibu-ibu yang bekerja diluar rumah banyak yang menggunakan IUD karena jangka panjang pemakaian dikarenakan ibu sibuk. Namun pada ibu yang tidak bekerja banyak menggunakan KB suntik karena mempunyai banyak waktu di rumah. Pekerjaan adalah kegiatan yang dilakukan seseorang sampai saat ini dalam rangka mendapatkan penghasilan (Notoatmodjo, 2005).

Berdasarkan teori tersebut dapat disimpulkan bahwa penggunaan AKDR sangat dipengaruhi oleh pendidikan ibu hal ini ditunjukkan dari hasil uji statistik chi-square yaitu $\rho$ value $0,029<0,05$ hal ini menunjukkan adanya hubungan bermakna anatara pendidikan ibu dengan pemakaian AKDR dengan demikian hipotesis awal menyatakan bahwa ada hubungan bermakna antara pendidikan ibu dengan pemakan AKDR terbukti secara statistik.

Pendidikan yang tinggi akan mempengaruhi penyerapan informasi oleh seseorang. Mereka yang berpendidikan tinggi akan lebih mudah menerima informasi tantang manfaat dan efek samping kontrasepsi. Namun demikian tidak semua yang berpendidikan tinggi menggunakan kontrasepsi IUD karena pemilihan kontrasepsi IUD tidak hanya diputuskan oleh perempuan saja, melainkan memerlukan dukungan dan partisipasi suami (Irawati, 2017).

Sedangkan hubungan pekerjaan dengan pemakaian AKDR berdasarkan hasil penelitian ini didapatkan bahwa tidak ada hubungan yang bermakna antara pekerjaan ibu dengan pemakaian kontrasepsi AKDR.

Para akseptor yang mempunyai usia yang matang lebih bisa memilih dan menerima informasi yang didapatnya sehingga mereka selalu aktif mencari informasi melalui penyuluhan dari petugas KB (Penyuluh Keluarga Berencana) ataupun lewat media massa. Tetapi ada juga sebagian kecil dari usia matang pengetahuannya kurang mungkin disebabkan akseptor tersebut kurang aktif dalam mendapatkan informasi ataupun kurang bergaul dengan masyarakat lainnya sehingga menghambat akseptor tersebut dalam menerima informasi.

Selain itu mengapa pekerjaan tidak berhubungan dengan pemakaian kontrasepsi AKDR kemungkinan karena pengambilan sampel terlalu sedikit sehingga penelitian ini menghasilkan hubungan yang tidak signifikan.

\section{SIMPULAN}

Ada hubungan yang signifikan antara pengetahuan ibu dengan pemakaian alat kontrasepsi AKDR di wilayah kerja Puskesmas Taba Kota Lubuklinggau. Tidak ada hubungan antara pekerjaan ibu dengan pemakaian alat kontrasepsi AKDR di wilayah kerja Puskesmas Taba Kota Lubuklinggau.

\section{SARAN}

Saran dari penelitian ini diharapkan dapat lebih meningkatkan penyuluhan mengenai alat kontrasepsi jangka panjang khususnya AKDR sehingga dapat meningkatkan jumlah akseptor MKJP, selain itu diharapkan dapat mengup-date dan menambah sumber kepustakaan tentang buku-buku, majalah mengenai Keluarga 
Berencana $(\mathrm{KB})$ dan jurnal kesehatan dan penelitian terdahulu yang berkaitan dengan penelitian, serta dapat memberikan informasi dan pengetahuan bagi peneliti yang akan datang dalam meneliti variabel lainnya seperti pendidikan, akses informasi, serta keterbatasan pilihan metode kontrasepsi dan sarana pelayanan yang berhubungan dengan pemakaian kontrasepsi AKDR dengan menggunakan metode-metode penelitian yang berbeda sehingga penelitian mengenai AKDR dapat terus dikembangkan.

\section{DAFTAR PUSTAKA}

Armainar, A. (2011). Faktor-Faktor yang Mempengaruhi Akaseptor KB dalam Memilih Alat Kontrasepsi dalam Rahim di Wilayah Kerja Puskesmas Minas Kabupaten Siak. Skripsi: STIKes HangTuah Pekanbaru

Asra, I. (2010). Faktor-Faktar yang Berhubungan dengan Penggunaan Alat Kontrasepsi Dalam Rahim Pada Akseptor KB di Wilayah Kerja Puskesmas Balai Makam Duri. STIKes HangTuah Pekanbaru

Biran, A. (2012). Buku Panduan Praktis Pelayanan Kontrasepsi. Jakarta: PT. Bina Pustaka Sarwono Prawirohardjo

BKKBN (2011). Greand desain pengendalin kualitas penduduk:BKKBN

BKKBN. (2009). Data CPR. Jumlah Penduduk. http://bkkbn.go.id

BKKBN. 2005. Keluarga Berencana dan Kesehatan Reproduksi. Jakarta: BKKBN

Depkes RI. (2011). Target Tujuan Pembangunan MDGs. Direktorat Jendral Kesehatan Ibu dan Anak. Jakarta

Gungde, G. (2008). Hubungan Kontrasepsi Suntik dengan Peningkatan Berat Badan Aksptor di BPS Eni Juniati Sutorejo Surabaya

Hanafi, H. (2008). Keluarga Berencana dan Kontrasepsi. Pustaka Sinar harapan: Jakarta Panduan Tehnik Konseling Pelayanan Kontrasepsi: Jakarta

Hurlock, E. B. (2004). Psikologi Perkembangan. Jakarta: PT. Gelora Aksara Pratama

Irawati, D. (2017). Faktor - Faktor yang Mempengaruhi Pemilihan Kontrasepsi IUD (Intra Uterine Device) di Desa Karangjeruk Jatirejo Mojokerto. Medica Majapahit, 9(2),126-41

Kementerian Kesehatan Republik Indonesia. (2013). Buletin Jendela Data dan Informasi Kesehatan. I. Jakarta: Pusat Data Dan Informasi Kemenkes RI

Liando, F., Runkat, M., Manueke, I. (2013). Faktor-Faktor yang Berhubungan dengan Penggunaan Alat Kontrasepsi Dalam Rahim (AKDR) di Wilayah Kerja Puskesmas Kecamatan Pasar Rebo Jakarta Timur. Jidan (Jurnal Ilm Bidan), 1(1), 145

Maulana, M. (2008). Panduan Lengkap Kehamilan. Jogjakarta: Kata Hati

Notoatmodjo, S. (2005). Pendidikan dan Perilaku Kesehatan. Jakarta: Rineka

Nursalam, N. (2002). Konsep dan Penerapan Metodologi Penelitian Ilmu Keperawatan. Jakarta: Salembada Medika

Pitriani, R. (2015). Hubungan Pendidikan, Pengetahuan dan Peran Tenaga Kesehatan dengan Penggunaan Kontrasepsi Intra Uterine Device (IUD) di Wilayah Kerja Puskesmas Rawat Inap Muara Fajar Pekanbaru. Jurnal Kesehatan Komunitas, $3(1), 25-28$

Prawirohardjo, S. (2003). Buku Panduan Praktis Pelayanan Kontrasepsi. Jakarta: Yayasan Bina Pustaka 
Rathi S, \& Jawadagi S. (2014). Study to Assess the Factors Affecting Acceptance to Intrauterine Device among Rural Women of Hirebagewadi, Belgaum. IOSR J Nurs Heal Sci, 3(2), 37-52. Available from: http://www.iosrjournals.org/iosrjnhs/papers/vol3-issue2/Version- 5/I03253752.PDF

Saifuddin, A. B. (2006). Buku Panduan Praktis Pelayanan Kontrasepsi. Jakarta: Yayasan Bina Pustaka

Suratun, S. (2008). Pelayanan Keluarga Berencana dan Pelayanan Kontrasepsi. Jakarta : Trans Info Media

Winkjosastro, H. (2008). Ilmu Kebidanan, Jakarta: Yayasan Bina Pustaka sarwono Prawiroharjo

World Health Organization. (2007). World Health Statistics 2007 [Internet]. Geneva, Switzerland: World Health Organization; 2007. Available from: http://www.who.int/gho/publications/ world_health_statistics/whostat2007. Pdf 